\title{
WOMEN'S LEADERSHIP IN INDONESIA CONTEMPORARY FIQH PERSPECTIVE
}

\author{
Hamka $^{1}$ \\ Misbahuddin $^{2}$ \\ Hasyim Aidid ${ }^{3}$ \\ Indra Satriani $^{4}$ \\ Syamsuddin 5 \\ IAIM Sinjai ${ }^{1}$, UIN Aluddin Makassar ${ }^{2}$, UIN Aluddin Makassar ${ }^{3}$, \\ STAI Yapnas Jeneponto ${ }^{4}$, IAI Assaddiyah ${ }^{5}$, \\ hamkaadolc@gmail.com 1,misbahuddin08121970@gmail.com², \\ satriani.idrus@gmail.com, ${ }^{4}$ samsuddin8508@gmail.com ${ }^{5}$
}

\begin{abstract}
This paper describes the leadership of women in Indonesia in contemporary fiqh. The method used is literature and describes the main problems in the research. The sub-problems that are addressed are the role of women in the era of the Prophet and contemporary fiqh in women's leadership in Indonesia. This study found that the involvement of women in the time of the Prophet was not restricted in social aspects, attending lectures, discussion partners and so on. Reflecting that social involvement in the Sasulullah era was very open to women, it is not appropriate and fair if women are limited in their space of movement in social participation or career. The paradigm of women "staying at home" is not in line with the Prophet's example in his time, especially in today's life, especially in Indonesia, which gives women the freedom to work. The explanations in the collective verses of the Qur'an and Hadith and social facts at the time of the Prophet, as well as historical facts in Indonesia, are evident in the involvement of women in all aspects, including being leaders in social, educational and political aspects. Women's political participation is in line with Indonesia's social and constitutional situation in opening up space for women to be involved in practical politics, including running for Regional Head and President. The potential of women in terms of leading the state (becoming heads of state) is very open and justified in Islam because no text contradicts contextually but provides the same rights and responsibilities as men in all aspects, including religion, social and culture. Political.
\end{abstract}

Keywords: Women's Leadership; Indonesia; Contemporary Fiqh

\section{PENDAHULUAN}

Indonesia is the fourth most populous country globally, with a population of 269,603.4 million, 135,337.0 million are male, and 134,266.4 are female. ${ }^{1}$ Based on this population, at least $87 \%$ are Muslim, indicating that Indonesia is a country with a majority Muslim population. ${ }^{2}$ Based on these data, it will be informed that the religion

\footnotetext{
${ }^{1}$ Aplikasi Badan Pusat Statistik, https://www.bps.go.id/indicator/12/1886/1/sum-populationhasil-projection-menurut-provinsi-dan-tipe-kelamin.html, diakses di 30 Maret 2021Viva.

${ }^{2}$ Viva BOdi Kusnandar, Indonesia merupakan negara dengan penduduk muslim terbesar di dunia. https://databoks.katadata.co.id/datapublish/2019/09/25/indonesia-negara-with-Populasi Muslim terbesar di dunia (30 Maret 2021)
} 
of Islam in Indonesia is substantial, so it is necessary to study Islamic fiqh in all aspects, including new matters.

Fiqh is a cultural interpretation of the verses of the Qur'an. Shari'ah is distinguished from fiqh based on intellectual history; namely, sharia is universal, permanent, while fiqh is a non-basic teaching, elastic, local and not permanent. The cultural interpretation developed by fiqh scholars since the second century Hijriyah was pioneered by Iman Abu Hanifah, Imam Malik, Imam Syafi'i and Iman Ahmad bin Hambal or known as the school of faith. They are known as moderate scholars but are still bound by the social phenomena in which they live, even arranged in a maledominated society, as was the case in the Middle East. ${ }^{3}$

The point of view that thinks that classical fiqh texts are still fundamental is maintained without any substantial changes that will regulate the current social order, as if forgetting the long journey of the four scholars in enforcing laws based on social phenomena in their time, so that certain things require re-examination in the sense of providing a new formula for responding to today's social facts, including restrictions on women.

As Husain Muhammad revealed that it is an irony in scientific thought if the way of thinking of fiqh by maintaining the texts of the book as it is, is still a common phenomenon and continues to be followed by most people, which has lasted for centuries to this day and is everywhere. Some even limit themselves to the products of the thoughts of certain mujtahids and reject other ideas. ${ }^{4}$

This opinion widely opens the doors of ijtihad to study and reformulate classical fiqh by considering new social facts. Women in politics in running for the head of state, limiting women's careers and so on. These issues are a challenge for Islamic fiqh because they are still a polemic amid society with the slogan that women stay at home. This also happens in other countries, such as India. As stated in the research results of Erica Selander et al., the journal produced one of the points related to restrictions for women going out of the house in India, even for their health needs. ${ }^{5}$ Many of these cases are still encountered in everyday life.

This paradigm seems to have the support of hadith and classical fiqh. On the other hand, there was a strong response that women seemed to be coded lower than men; there was even an assumption by some people that Islamic fiqh was discriminatory against women. The phenomenon of these two opinions sometimes becomes a polemic of its own, thus encouraging contemporary fiqh related to women's leadership in Indonesia to discuss women at the time of the Prophet and contemporary fiqh in women's leadership.

\section{THEORETICAL REVIEW}

\section{A. Contemporary Fiqh}

\footnotetext{
${ }^{3}$ Ipandang, "Fiqh Perempuan, Kekinian Dan KeIndonesiaan (Telaah Kritis Membangun Fiqh Berkeadilan Gender)" Jurnal Al-Maiyyah 8, no. 1 (2015): 79-98.

${ }^{4}$ Husein Muhammad, Agama dan Jenis Kelamin (Cet.I; IRCiSod: Sampang, 2019), h.270-271.

${ }^{5}$ Erica Sedlander et al., "How Gender Norms Affect Anemia in Select Villages in Rural Odisha, India: A Qualitative Study,” Nutrition 86 (2021): 111159, https://doi.org/10.1016/j.nut.2021.111159.
} 
Studies in contemporary fiqh are materials that are not much different from masail al-Fiqh-iyah. Because basically, the study of the subject matter in the study of contemporary fiqh is the same as the main subject of masail fiqh-iyah. The fines only lie in the present nature, namely the discussion that has not been discussed in the fiqhiyah issue. So conclusion Qutbuddin Aibak said in his conclusion that contemporary fiqh is another name for masail fiqh-yah. Although there are still differences in it related to specific goals to be achieved. The problems in the discussion of contemporary fiqh studies are entirely new. Classical scholars sought problems that have occurred or were discussed and solutions, but still, these problems reappear. ${ }^{6}$

This explains the importance of ijtihad to produce contemporary fiqh in responding to problems that have developed until now, such as women's leadership. Ijtihad is increasingly needed in the contemporary era to answer today's challenges where many problems arise amid a society requiring legal istimbath, namely contemporary fiqh, so that the undergraduate factor is not entrusted is it brave or not, but the ability to ijtihad factor.7 Seriousness in ijtihad is necessary considering the problems faced are prevalent in society both for and against. It will impact the resulting fiqh decisions where the community will make evidence for the results of the ijtihad and make it a product of contemporary fiqh.

\section{B. Women's Constitution and Politics in Indonesia}

Indonesia still adheres to a patriarchal culture, although it has begun to erode little by little due to the times. Women have begun to dare to express their opinions in public spaces. This opportunity has been regulated in a law which explains that every citizen has the right to express his opinion, both men and women. Article 281 (2) of the 1945 Constitution states that "everyone has the right to be free from discriminatory treatment on any basis and has the right to protection from discriminatory treatment". In Udang-Udang No. 7 of 1984, the government is obliged to maintain and fulfill the rights inherent in women, both individuals and groups. in this case women have the right to participate in politics, which is their right as citizens, supported by Law no. 2 of 2008 which states that political parties must participate at least $30 \%$. in its management and establishment, ${ }^{8}$ including the nomination of its members in legislative elections.

\section{RESEARCH METHODOLOGY}

This paper is a literature study that describes social phenomena related to the paradigm of women's leadership in Indonesia. Reviewing the texts of the Qur'an and Hadith, reviewing the history of the Prophet and his companions regarding the involvement of women both socially and politically, then examining social phenomena and the legality of women in participating in the Indonesian political arena. h. III-IV.

${ }^{6}$ Qutbuddin Qutbuddin Aibak, Kajian Fiqh Kontemporer(Cet. I; Yogyakarta: Kalimedia, 2017),

${ }^{7}$ Fathurrahman Fathurrahman, "Pengembangan Metode Ijtihad Kontemporer," Jurnal Diskursus Islam 2, no. 2 (2014): 225-43.

${ }^{8}$ Mircea Eliade, dkk., Ensiklopedia Agama (New York: Macmillian Publishing Company, 1987). 


\section{WOMEN IN THE TIME OF THE RASULULLAH}

The wife of the Prophet Muhammad. is a woman who is independent in running her business, apart from that Khadijah is active in supporting the struggle of the Prophet's da'wah in full to promote Islam. Khadijah reflects women who are free, firm and do not match the assumption that women are passive in socializing during society, so they are known as mothers for believers. ${ }^{9}$

Based on the classical Islamic literature quoted by al-Tabari and Tabaqat Ibn Sa'ad who released about the role of women in Islamic society. After the Prophet migrated to Medina with the emigrants, the women took allegiance, they played a role in religious worship on Islamic holidays and heard the Prophet's studies. ${ }^{10}$ Even Ibn Sa'ad in his Tabaqat reveals that they participated in discussions or partners with the Prophet on religion and life issues, not as passive or obedient followers. ${ }^{11}$

After the Prophet. died where the dynamics of Islamic leadership occurred, but Aisyah Binti Abu Bakar emerged as a woman who took on a significant social role even in the political sphere. Illustrated when in his attitude against the power of Ali bin Abi Talib the war of Jamal so that his position as the main reference in religious affairs in terms of women. ${ }^{12}$

Some of these women's roles with different times and roles made them a pilot project in women's social and political roles in the time of the Prophet and his companions. Because it changed after the dynastic period where the social role of women gradually receded along with the development of the times and the expansion of Islamic territory dominated by male rulers. The role of women can be traced to the concept of equality between men and women, which is clearly stated in the Qur'an, and is an authentic record that has occurred in history. Many things get called simultaneously with men, including socio-political. For example QS, al-Ahzab/33:3536 which translates:

"Verily, Muslims and Muslims, believers and believers, obedient men and women, pious men and women, patient men and women, humble men and women, men and women who give in charity, men and women who give in charity. men and women who fast, men and women who keep their private parts, men and women who mention Allah a lot, for them Allah has provided forgiveness and a good reward. it is not appropriate for the believer and the believer, if Allah and therefore His Messenger has decreed, then there will be (other) options for them regarding their affairs. Whoever disobeys Allah and His Messenger, then indeed he has strayed into a clear error. "'l3

${ }^{9}$ Muhammad Ibnu Sa'd, Al-Tabagat al-Kubra ( Bairut: Dar al-Qutub al-Ilmiyyah, 1990), h. 130.

${ }^{10}$ Abu Syaqqah, 'Abd al-Halim Muhammad. Tahrir al-Mar'ah fi 'Ahr ar-Risalah: Dirasah 'An al-Mar'ah Jami'ah li Nushush al-Qu'ran wa Shahihai al-Bukhari wa Muslim. (Kuwait: Dar al-Qalam, 1995), h. 88.

${ }^{11}$ Muhammad Ibn Sa'ad, Al-Thabaqat al-Kubra, h. 278.

12 Al-Afgahani, Sa'id. Pemimpin Perempuan Dalam Politik; Kajian Sejarah Pemerintaha Aisyah (Aisyah Wa Siayasah), Terj. Syarifuddin (Yogyakarta: Perpustakaan Pelajar, t.t.)

${ }^{13}$ Qur'an Inwor Kemenag Tahun 2019 
This verse clearly explains the simultaneous human identity between men and women in various matters related to religious/spiritual, ethical, social and political obligations without segregating by gender. The similarity of roles and responsibilities described in the verse refutes some negative assumptions and injustices against women for their potential in all aspects.

First, generalized stereotypes are passed down from generation to generation and include ideas such as that women are born with inferior statuses; woman is Eve's creation; girls are seen as property; men and women are not equal; humans are superior because God ordained them to be higher; sin stems from the ingrained evil and weakness of women; and women may not be leaders because of their vulnerability. ${ }^{14}$ Second, Revealing that despite Islamic guidelines towards truth and justice in work, tribal and Bedouin traditions limit women's work through patriarchal interpretations of Islam. ${ }^{15}$

Both of these assumptions are completely inconsistent with Islamic teachings, even if there are facts that occur, they are casuistic so that a more complex study is needed in comparing other facts that occurred during the time of the Prophet, including the laws narrated in the Qur'an, because life history should be The Prophet and women exemplified the roles of women in various aspects, including social and even political ones.

\section{FIQH CONTEMPORARY IN WOMEN'S LEADERSHIP IN INDONESIA}

Women in contemporary fiqh are interesting discussions because they always get debates among jurists regarding their roles in social and political aspects. One of the highlights for women is involvement in practical politics who will have the potential to become leaders amid society or become heads of state based on QS al-Nisa $1 / 4: 34$

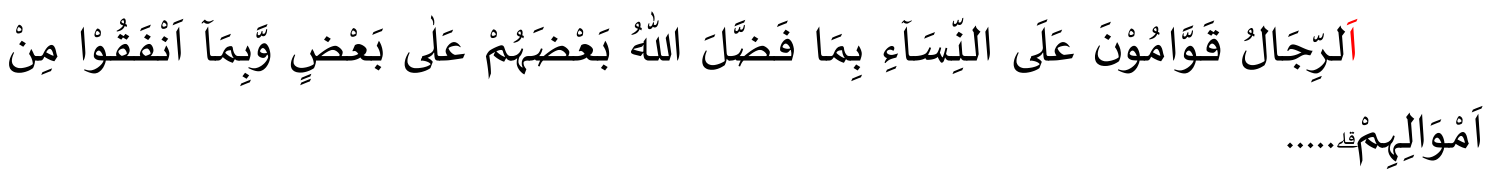

Translate:

"Men are responsible for women because Allah has favored some of them (men) over others (women) and because they (men) have spent part of their wealth. Righteous women are those who obey (to Allah) and ensure themselves when (her husband) is not around because Allah has taken care of (them). "16

According to Ibn Kathir in his commentary, men are administrators for women, namely leaders, the top who controls and educates him if he deviates. Men are more

\footnotetext{
${ }^{14}$ Hannelie J. Wood, "Gender Inequality: The Problem of Harmful, Patriarchal, Traditional and Cultural Gender Practices in the Church," HTS Teologiese Studies / Theological Studies 75, no. 1 (2019): 1-8, https://doi.org/10.4102/hts.v75i1.5177.

15 Tamer Koburtay Dkk, "Implications of Religion, Culture, and Legislation for Gender Equality at Work: Qualitative Insights from Jordan,” Journal of Business Ethics 164 (2020): 421-36.

${ }^{16}$ Qur'an In Word Kemenag Tahun 2019
} 
afdal than women, someone is better than women, so prophecy is only for men who can become kings. ${ }^{17}$

Based on this interpretation, it is textually interpreted that women do not have the opportunity to lead in society, nation and state, because women's position is lower than men. Then this paradigm is supported by a hadith which states that a people is not lucky if a woman leads it, said the Messenger of Allah:

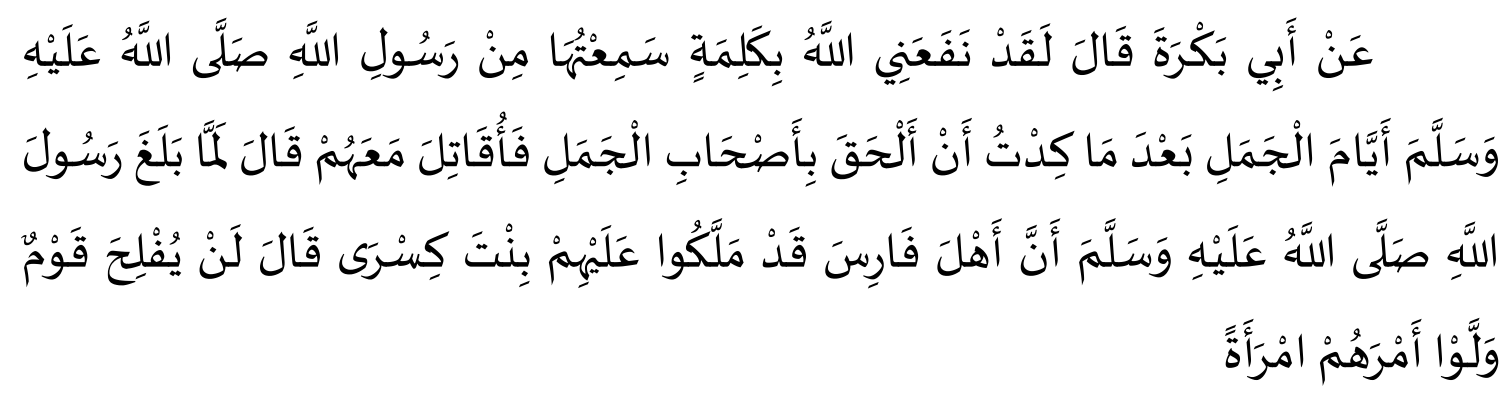

Meaning:

"From Al Hasan from Abu Bakrah he said; Indeed Allah has benefited me with a sentence that I have heard from the Messenger of Allah, -that is during the war of Jamal, one time I was on the verge of joining the camel riders and I wanted to fight with them. She says; When it came to the Prophet sallallaahu 'alaihi wasallam, that the Persians had been led by a daughter of the daughter of the king's daughter Kisra, he said: "A people will not be lucky, if a girl leads it. "'l8

Based on these two arguments, this further strengthens certain groups in interpreting the textual arguments without a deeper study. In drawing conclusions they tend to get negative judgments from women activists with discriminatory views. Islam is certainly born based on rahmatanlilalamin so it is not in line if it gives a sense of discrimination against certain groups, including women.

The case needs an in-depth understanding to respond to it, at least examining it in a complex manner including historical aspects. Some arguments appear to limit women from being leaders in a country or kingdom. The views of some scholars differ, among scholars interpreting that the word al-Rijal in the sense of husbands is $\mathrm{M}$. Quraish Shihab with the consideration of the considerations in the continuation of the verse because basically, wives should be fed from part of their husbands' assets. ${ }^{19}$

This meaning informs that the leader in the context of qawwamuna is aimed at married men so that they control, manage and guide their wives in married life. As Ust. Hidayat in the Islamic da'wah youtube channel explained that married men were renamed al-Rijal and linked in qawwamun. Al-Rais means leader/protector in the state administration (President). The leader/protector in the special worship of prayer is called the Imam. The leader/guardian who is closer is called Wali-Auliyaa'. If the leader/protector/supporter, in a more limited context and contains worship values,

\footnotetext{
${ }^{17}$ Aplikasi Tafsir Ibnu Katsir,Surah al-Nisa. h. 23

${ }^{18}$ Hadits-hadits nabi. https://carihadis.com/Shahih_Bukhari/4073

${ }^{19}$ Muhlis Muhtar, "Fiqh Perempuan Kekinian Dan Keindonesiaan," Ash-Shahabah V (n.d.): 36-
} 44. 
qaaim/qwwamuun. ${ }^{20}$ It further strengthens that the verse emphasises the husband's leadership over his wife in household matters.

As for those related to the hadith about the destruction of an area / kingdom led by a woman, the Prophet said. After listening to the chronology of succession in Persia where the daughter of the king of Kisra named Syairawaih bin Kisrah bin Barwaiz rose as queen in Persia. The coronation of his daughter was a compulsion, because his brother was killed by the close family of the head of State for chaos and various murders. The chaos was a reply that Allah gave to the king of Kisrah who tore up the letter of the Prophet's invitation to cooperate to embrace Islam.. ${ }^{21}$

Prof. Quraih Shihab explained that this hadith was not generally accepted, because it was only addressed to the Persian community at that time, not to all people in all matters. ${ }^{22}$ So that directly there is no general prohibition for women to become leaders during society, including becoming kings or leaders in the country.

Then there is a chronology that needs to be understood that the Prophet issued a proposition for the phenomenon of the overthrow of power experienced by the Persian empire. First, where the situation of the kingdom is in a chaotic atmosphere so that it is possible that chaos will continue if women lead it. Second, the woman still does not have the experience of being the head of a kingdom because her older brother who is automatically prepared, not the woman, has adequate support and scientific capacity in leading a kingdom.

Based on the two arguments that discuss the authority of women and the chronology experienced by the Persian empire, it provides a lesson that women may lead a kingdom or region in a peaceful and peaceful situation and a state of readiness. In the sense of having scientific capacity about the state and its management. So that the argument may be used in certain cases and certain cases. However, the current case of women cannot be limited in terms of being heads of state because the potentials of women today are already equal to men in all aspects, including leading heads of state.

As Wahyudin Naro concluded in his journal, specifically in Islam no argument prohibits and requires women's leadership. However, it relies on the capabilities and advantages of each individual, including men. So it cannot be denied that men and women are a partnership in all respects, except in certain natural conditions inherent in both men and women. ${ }^{23}$ This research provides a wide space for women's participation in practical politics to get a leadership position in a country.

The involvement of women in politics gives its color and shows that the responsibility of a state is a shared responsibility, including women. Accountability becomes whole for every soul, both men and women in all elements of the political community, economy, office, thought and association. For the woman in question, her obligations to parliamentary representatives and public organizations are provided

${ }^{20}$ Adi Hidayat, Lelaki Pemimpin Wanita https://www.youtube.com/watch?v=6SAvUsg$5 \mathrm{Ls} \& \mathrm{t}=339 \mathrm{~s}(31$ Maret 2021

${ }^{21}$ Muhlis Muhtar, "Fiqh Wanita Kontemporer dan Keindonesiaan, Lihat Abu Fallah Abd alHayy bin al-Imad al Hanbali, Syadrat al-Dzahab Fi Akhbar man Dzahab volume I. Dar al-Fikr, (1979).

22 Wahyuddin Naro, “Artikulasi Kesetaraan Gender Dalam Pendidikan ( Persfektif Islam )," Jurnal Diskursus Islam 3 (2015): 311-28.

${ }^{23}$ Wahyuddin Naro, Artikulasi Kesetaraan Gender Dalam Pendidikan (Perspektif Islam) 
because her culture and formation are scientifically above a good level of understanding in these matters. ${ }^{24}$

as QS al-Taubah/9:71

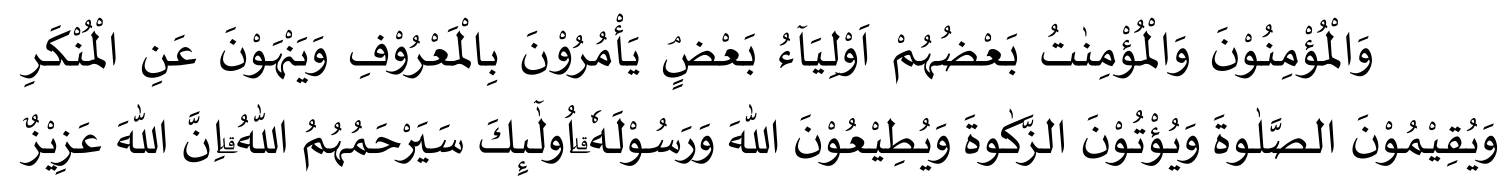

Translate:

"And those who believe, together with their perfect faith, male and female, some helpers to others in matters of truth and them. It is clear in their attitude and behavior, namely that they command to try and do what is right, prevent what is evil, pray, pay zakat, and obey Allah and His Messenger. they are people who Allah blesses. Verily, Allah is All-Powerful to protect them with His mercy, Wise with all His bounties. ${ }^{25}$

This verse teaches that the purpose of a believer's life is to succeed in pleasing Him, also the most important thing is if what is done and what is produced can lead to a glory before Allah. The argument gives a mandate to all communities of believers and believers who provide enlightenment, on the other hand Allah also gives responsibility for both of them in maintaining the trust so that they are not forgiven if they are negligent of it. ${ }^{26}$ The equation of position in this verse explains that women and men have the same obligations in carrying out Allah's commands as servants.

The power of legality over women and men that the responsibility for them is the same in maintaining peace in both the political, social, and other cultivation systems. Men and women have an important role in the development of the nation and the state, so the position of women at this time is reasonable to occupy an important position because they have a contribution in the field of religion, nation and state, especially in Indonesia, including being a leader.

The leadership competencies of men and women are no longer suitable to be positioned differently as long as they have a capable leadership capacity as Rasulalla has also refused his friend who asked for a position (wanting to be a leader in an area) as he said which means:

"O Abdul Rahman Bin Samurah, never ask to be the pacesetter. Indeed, leadership is given to you by asking, then you will tend to take responsibility as a pioneer. And if the position is given, without browsing asking, then you may get help, if you have taken your oath of office and see that someone else is best for the position then cancel your oath and give the position to a healthier person."27

${ }^{24}$ Mohammed Osman El-Khost, Fiqh Wanita dari Klasik ke Modern, trans. Abu Ihmadullah (Cet.I; Solo: Tiga Serangkai: Solo, 2018), h. 296

${ }^{25}$ Kementerian Agama Republik Indonesia, al-Qur,an dan Terjemahan,h. 291

${ }^{26}$ Mohammed Osman El-Khost, Fiqh Wanita dari Klasik sampai Modern, h.296

${ }^{27}$ Toha Andiko, "UPAYA MERAIH JABATAN PEMIMPIN PERSPEKTIF HADIS AHKAM," Mizani 5, no. 2 (2018): 25-36. 
This hadith informs that even men are not fully justified in leading if they do not have the competence and capacity to lead, even if they are men, so that this hadith is substantially not based on gender but on the ability and knowledge to manage the position, so that they can become protectors for every citizen. as explained by Hamza Hasan and Laode Ismai Ahmad in their journal, namely: السلطان ولي من لاولي له "A leader is a ward to whom without ward". ${ }^{28}$ So that the deposit of the Prophet in one's leadership of a nation, both women and men, is to protect its citizens and benefit the nation and state.

Moreover, nowadays, with time, times have changed, social phenomena have changed so that women's rights are no longer compared to men's. Suppose other countries such as the Middle East have a different political situation from Indonesia today. In that case, it still limits women in several aspects, but they have made improvements to provide public spaces for women to work. It is different in Indonesia, where since the colonial period, women have emerged as leaders in several cases, such as Cut Nyak Dien in Aceh and education pioneer R.A. Kartini. The two female figures reflect Islamic female figures, but none of the Ulama have questioned their leadership with their respective knowledge and passion. Based on the historical facts of Rasululla, Friends to the facts of the pioneers of Indonesian women, contemporary fiqh is here to argue for the law to answer the pros and cons related to women's leadership in Indonesia, whose social atmosphere provides equal rights with men in social and political aspects, both to nominate as the constitution guarantees people's Representatives, Regional Heads, and the President and protection for women in the nation and state without discrimination.

\section{CONCLUSION}

Moreover, nowadays, with time, times have changed, social phenomena have changed so that women's rights are no longer compared to men's. Suppose other countries such as the Middle East have a different political situation from Indonesia today. In that case, it still limits women in several aspects, but they have made improvements to provide public spaces for women to work. It is different in Indonesia, where since the colonial period, women have emerged as leaders in several cases, such as Cut Nyak Dien in Aceh and education pioneer R.A. Kartini. The two female figures reflect Islamic female figures, but none of the Ulama have questioned their leadership with their respective knowledge and passion.

Based on the historical facts of Rasululla, Friends to the facts of the pioneers of Indonesian women, contemporary fiqh is here to argue for the law to answer the pros and cons related to women's leadership in Indonesia, whose social atmosphere provides equal rights with men in social and political aspects, both to nominate as the constitution guarantees people's Representatives, Regional Heads, and the President and protection for women in the nation and state without discrimination.

${ }^{28}$ Hamzah Hasan and La Ode Islmail Ahmad, "The Correlation Between Human Rights and Human Obligations (An Analysis of Islamic Criminal Law),” Diskursus Islam 8, no. 2 (2020): 71-76. 


\section{BIBLIOGRAPHY}

Abu Shaqqah, Abdu al-Halim Muhammad. Tahrir al-Mar'ah Fi Ahr al-Risalah: Dirasa an al-Mar'ah Jami'ah Li Nushush al Qur'an Wa Shahihai al-Bukhari Wa Muslim. Kuwait: Dar al-Qalam, 1995

Adi Hidayat, Lelaki Pemimpin Wanita https://www.youtube.com/watch?v=6SAvUsg5Ls\&t=339s(31 Maret 2021

Aibak, Qutbuddin. Kajian Fiqh Kontemporer. Cet. I; Yogyakarta: Kalimedia, 2017.

Al-Afgahani, Sa'id. Pemimpin Perempuan Dalam Politik; Kajian Sejarah Pemerintaha Aisyah (Aisyah Wa Siayasah), Terj. Syarifuddin. Yogyakarta: Perpustakaan Siswa, t.t.

Aplikasi Badan Pusat Statistik, https://www.bps.go.id/indicator/12/1886/1/sumpopulation-hasil-projection-menurut-provinsi-dan-tipe-kelamin.html, diakses di 30 Maret 2021Viva

Aplikasi Tafsir Ibnu Katsir,Surah al-Nisa.

BOdi Kusnandar, Indonesia merupakan negara dengan penduduk muslim terbesar di dunia. $\quad$ https://databoks.katadata.co.id/datapublish/2019/09/25/indonesianegara-with-Populasi Muslim terbesar di dunia (30 Maret 2021)

Eliade, Mircea. dkk., Ensiklopedia Agama. New York: Perusahaan Penerbitan Macmillian, 1987.

hadits Nabi. Https://carihadis.com/Sahih_Bukhari/4073

Ibnu Sa'd, Muhammad. Al-Tabagat al-Kubra. Bairut: Dar al-Qutub al-Ilmiyyah, 1990

Mohammed Osman El-Khost, Fiqh Wanita dari Klasik ke Modern, trans. Abu Ihmadullah. cet. SAYA; Tiga Seri: Solo, 2018.

Muhammad, Husein. Agama dan Jenis Kelamin. cet. SAYA; IRCiSod: Sampang, 2019.

Muhlis Muhtar, "Fiqh Wanita Kontemporer dan Keindonesiaan, Lihat Abu Fallah Abd al-Hayy bin al-Imad al Hanbali, Syadrat al-Dzahab Fi Akhbar man Dzahab volume I. Dar al-Fikr, 1979. Qur'an Inword Kemendikbud Tahun 2019.

Andiko, Toha. "UPAYA MERAIH JABATAN PEMIMPIN PERSPEKTIF HADIS AHKAM.” Mizani 5, no. 2 (2018): 25-36.

Fathurrahman, Fathurrahman. "Pengembangan Metode Ijtihad Kontemporer." Jurnal Diskursus Islam 2, no. 2 (2014): 225-43.

Hasan, Hamzah, and La Ode Islmail Ahmad. "The Correlation Between Human Rights and Human Obligations (An Analysis of Islamic Criminal Law)." Diskursus Islam 8, no. 2 (2020): 71-76.

Ipandang. "Fiqh Perempuan, Kekinian Dan KeIndonesiaan (Telaah Kritis Membangun Fiqh Berkeadilan Gender)." Jurnal Al-Maiyyah 8, no. 1 (2015): 79-98.

Muhtar, Muhlis. "Fiqh Perempuan Kekinian Dan Keindonesiaan." Ash-Shahabah V (n.d.): $36-44$. 
Naro, Wahyuddin. "Artikulasi Kesetaraan Gender Dalam Pendidikan ( Persfektif Islam )." Jurnal Diskursus Islam 3 (2015): 311-28.

Sedlander, Erica, Sameera Talegawkar, Rohini Ganjoo, Chandi Ladwa, Loretta DiPietro, Aika Aluc, and Rajiv N. Rimal. "How Gender Norms Affect Anemia in Select Villages in Rural Odisha, India: A Qualitative Study." Nutrition 86 (2021): 111159. https://doi.org/10.1016/j.nut.2021.111159.

Tamer Koburtay Dkk. "Implications of Religion, Culture, and Legislation for Gender Equality at Work: Qualitative Insights from Jordan.” Journal of Business Ethics 164 (2020): 421-36.

Wood, Hannelie J. "Gender Inequality: The Problem of Harmful, Patriarchal, Traditional and Cultural Gender Practices in the Church." HTS Teologiese Studies / Theological Studies 75, no. 1 (2019): 1-8. https://doi.org/10.4102/hts.v75i1.5177. 